\title{
Thinking About the Importance of and Developing Physician and Surgical Leaders
}

Joe Doty*

Executive Director, Feagin Leadership Program, USA

ISSN: 2578-0379

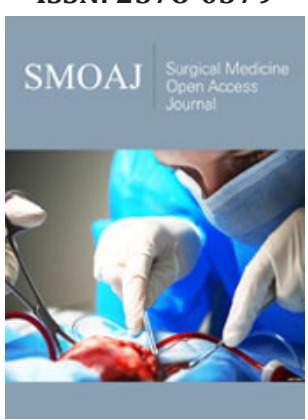

*Corresponding author: Joe Doty, Executive Director, Feagin Leadership Program, USA

Submission: 㓪) July 02, 2019

Published: 柴July 10, 2019

Volume 2 - Issue 4

How to cite this article: Joe Doty. Thinking About the Importance of and Developing Physician and Surgical Leaders. Surg Med Open Acc J.2(5). SMOAJ.000548.2019. DOI: $10.31031 /$ SMOAJ.2019.02.000548.

Copyright@ Joe Doty, This article is distributed under the terms of the Creative Commons Attribution 4.0 International License, which permits unrestricted use and redistribution provided that the original author and source are credited.

\section{Opinion}

This is literally a thought piece for those interested in the future of medicine and healthcare. How often do medical school deans, department chairs, and program directors ask themselves: "How well are we doing in preparing our students, residents and fellows to be leaders in healthcare?" And if they are asking that question, what do they mean by leaders? Another way to ask the question is to consider how much of UME and GME prepares students and residents to be leaders in healthcare? And yes, again, what is meant by the word leaders? When we say leaders, are we looking for the most talented and gifted surgeon? Are we looking for the physician with the most publications or the most grants? Is a department chair a leader simply because they are a department chair?

How important is it for a surgeon to make all members of the surgical team feel as if they are valued members of team? Does this include environmental services and the sterile processing unit? How do we train and education physicians and surgeons in this domain? How important is it for physicians to ensure all of the 'behind the scenes' people feel as if they are valued members of the team? How do we train and education physicians and surgeons in this domain?

A way to look at healthcare leaders are those influence others for the benefits of patients and patient populations. Here, the key words are influence others. How do we train and education physicians and surgeons to effectively influence others? And finally, a data point that seems appropriate to help answer some of these questions, or at least get the discourse going: "Omission of discourse is not value neutral education [1]. There is no such thing. Omission is a powerful, even if unintended signal, that these issues are unimportant." .

\section{References}

1. Piper T, Gentile M, Daloz PS (2007) Can ethics be taught: Perspectives, challenges, and approaches at the Harvard Business School. Boston (MA): Harvard Business School, USA p. 13. 